\title{
Chinese Coal and Sustainable Development
}

Jean-Marie Martin-Amouroux

\section{(2) OpenEdition}

Journals

Édition électronique

URL : http://journals.openedition.org/chinaperspectives/1233

DOI : 10.4000/chinaperspectives. 1233

ISSN : 1996-4617

\section{Éditeur}

Centre d'étude français sur la Chine contemporaine

Édition imprimée

Date de publication : 15 janvier 2007

ISSN : 2070-3449

\section{Référence électronique}

Jean-Marie Martin-Amouroux, «Chinese Coal and Sustainable Development », China Perspectives [En ligne], 2007/1 | 2007, mis en ligne le 08 avril 2008, consulté le 28 octobre 2019. URL : http:// journals.openedition.org/chinaperspectives/1233; DOI : 10.4000/chinaperspectives.1233

(c) All rights reserved 
(1)

\section{Chinese Coal and Sustainable}

Development

IEAN-MARIE MARTIN-AMOUROUX

A dust cloud over the Pacific visible from orbiting satellites, an alarming growth in mercury content throughout the biosphere in North America, global $\mathrm{CO}_{2}$ emissions greater than those of the United States from 2009: the formidable growth of China's thermoelectric generating capacity, based on coal production that crossed the threshold of two billion tons (2Gt) in 2005, is becoming one of the major industrial evolutions threatening the global environment. What is more, while the developed world's ecological impact should, in the future, be moderated by the slowdown in energy growth and far-reaching technological changes, China's impact is only now beginning to make itself felt. Its current consumption per capita of 1.25 tons equivalent petroleum (TEP) and of $1,607 \mathrm{kWh}$ is still closer to the average of developing countries than to that of the developed world $(4.73$ and 8,204$)$. Who, and in the name of what principle, could demand of China that it willingly renounces modernisation, which cannot be achieved without an increased supply of electricity, fuelled by coal, the only abundant and cheap energy source at its disposal? ${ }^{(1)}$

$\mathrm{B}$ oth at the local and the global level, the environmental degradation resulting from China's economic growth thus seems inevitable for the next few decades. On the other hand, the question concerning the forms of and the timeframe for the reactions that this degradation will provoke remains open. Atmospheric pollution in the cities and its cortege of premature deaths from pulmonary disease, the degradation and the warming of water in industrial regions, the premises of climate change (the winter of 2006-2007 has been the warmest for 167 years in Beijing) are no longer ignored ${ }^{(2)}$. Legislative initiatives have sometimes been taken by the central authorities directed against certain provincial and local leaders. Chinese industries, both in the electricity and coal-producing sectors, are progressively adopting technologies that are as efficient as those being used in the United States and Europe. In some cases, they are even demonstrating more boldness. How far will they go on this path? Will the beneficial environmental effects that can be anticipated succeed in offsetting the inevitable degradation already forecast? When could it be possible for the rising trajectories of greenhouse gas emissions (GGS) to be reversed?

\section{Coal in China's energy land- scape}

\section{Irresistible growth in energy and electricity}

From 1980 to 2005, China accomplished the feat of ensuring that its GDP grew at an average annual rate of $10 \%$ while limiting to $5 \%$ the growth rate in its consumption of primary energy sources. One part of the discrepancy has not been voluntary, as is attested to by the energy shortfalls that recur in the cities and even more so in the rural areas condemned to rely on supplies that have been made precarious by the increasing scarcity of biomass (crop waste and firewood). The other, most important part has resulted from a sharp increase in the efficiency of coal use through the modernisation of thermal power stations and high energy consuming industries: coking, steel-making, cement production, chemicals, non-ferrous metals. Result: the energy intensity of GDP decreased by more than $60 \%$ up to 2001 , before stabilising and then setting off on an upward trend again ${ }^{(3)}$. Is the evolution over the last four years nothing more than a stage, as in 1988-89, on the path of a long decline in energy intensity, or does it signify a reversal of the trend? Adhering to the first premise of this question, the Eleventh Five-Year Plan (2006-2010) has set as a target a new reduction of

1. To measure the distance already covered and the road still to be travelled, it should be remembered that the number of inhabitants without access to electricity has dropped from 245 million in 1979 to 20 million in 2004. Thomas C. Heller, "Diversifier la production électrique en Chine," in Pierre Jacquet, Laurence Tubiana (eds.), Regards sur la terre. Dossier Energie et changement climatique, Paris, Presses de Sciences Po, 2006, pp. 119-130.

2. Geoffrey York, "Will China be able to take the heat?", Globe and Mail, 7 February 2007.

3. Among the numerous works that have tackled the question, reference can be made to: Jeffrey Logan, "Diverging Energy and Economic Growth in China: Where Has All The Coal Gone?", Pacific and Asian Journal of Energy, vol. $11 \mathrm{n}^{0}$ 1, pp. 1-13, and more recently to: Ma Chunbo and David I. Stern, "China's Changing Energy Intensity Trend: A Decomposition Analysis", Rensselaer Working Papers in Economics, $n^{\circ} 0615$, December 2006. 



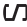

$\geq \quad$ in the history of the electricity industry: $50 \mathrm{GW}$ in 2004,70 in 2005, 102 in 2006 and possibly 90 in $2007^{(9)}$. At a stroke, the projection of 950GW in 2020, drawn up in 2004 by the National Development and Reform Commission (NDRC), is already null and void. The Chinese electricity industry is now aiming at power capacity in the magnitude of 1,200 to 1,300GW, persuaded that it will have to satisfy an electricity demand that will be greater than 5,000 TWh in 2020. In the longer term, production of 12,000 TWh in 2050 seems considerable, but it would only supply 6,480 $\mathrm{kWh}$ for each inhabitant, that is $20 \%$ less than the current average consumption in developed countries.

\section{Coal, a fuel without serious competitors}

How can this amount of electricity be produced? Excluding autogeneration of electricity by industry using small diesel engines, which are going to disappear, the generation capacity that supplied the public networks in 2006 was made up of hydroelectric power stations (24\%) and some other renewable sources $(0.7 \%)$, nuclear power stations $(2 \%)$, gasfired thermal power stations $(2.3 \%)$ and coalfired thermal power stations $(71 \%)$. The share of this last sector was voluntarily reduced to $66 \%$ in 2000 in the name of a diversification of electricity production that benefited the protection of the environment. Very quickly, however, the development of the other sectors encountered several obstacles. Hydroelectric power has progressed and will continue on this path, as its economic potential is still considerable, but the installations, especially when they are gigantic, require long lead times (officially launched in 1994, the Three Gorges project will not supply all of its planned 18GW until 2009), as well as certain environmental safety measures (Wen Jiabao, prime minister, is said to have intervened personally to suspend another very big project on the $\mathrm{Nu}$ river ${ }^{(10)}$. Since the first two reactors at Daya Bay, the Chinese nuclear industry has constructed nuclear production capacity of $6.2 \mathrm{GW}$ in twenty years. It has proceeded at this voluntarily prudent rate out of a concern to master the whole field (construction of reactors and fuel cycle) before embarking on the target of $40 \mathrm{GWW}$ by 2020 , which will represent, at best, $3 \%$ to $4 \%$ of the installed power capacity. Neither the efforts already undertaken to give advantage to the small hydroelectric power stations (capacity less than $10 \mathrm{MW}$ ), wind power and biogas in the remote rural regions, nor the law of 28 February 2005 that set at $20 \%$ the share of renewables in the supply by 2050, should change the marginal character of these energy sources in the overall electricity production in the next few decades ${ }^{(I I)}$. This is even more true as the distance between the locations in the west where the largest part of their potential is situated and the large centres of consumption on the southeast coast reduces still further a competitiveness that is already undermined by the intermittency and the dispersal of these energy sources.

Within the framework of the Tenth Five-Year Plan (20012005), gas-fired thermal powers stations appeared to provide a solution capable of rapidly and cleanly satisfying the demand of the large agglomerations on the southeast coast, but it had to face disappointment. The national production of $50 \mathrm{Gm}^{3}$ in 2005 , of which $12 \mathrm{Gm}^{3}$ is transported via the "West-East" gas pipeline put into service in October 2004 and, with $5 \mathrm{Gm}^{3}$ of Australian gas gasified at the terminal in Guangdong since 2006, is intended as a prority for industry (the chemical industry in particular) and for urban residential usage. Unless the growth in national production is more rapid than foreseen, the $60 \mathrm{GW}$ generated by gas-fired thermal power stations planned for 2020, of which 18GW will come from liquid natural gas (LNG), will therefore not see the light of day, as the evolution of international gas prices will by then have moved too far away from the 2.2 $\$ / \mathrm{MBtu}$ (British thermal unit) of the first contract with Australia (the Guangdong terminal) and even from the 3.8\$ /MBtu of the contract with Indonesia (the Fujian terminal, operational in 2009)(12). Coal thus has every chance of remaining China's principal source of electricity for a long time, based on installed capacity that will represent $64 \%$ of total generation in 2020 and $48 \%$ in 2050 (see table 1). The competitiveness of the sector is related to the capacity of Chinese electromechanical construction to supply thermoelectrical $\mathrm{kW}$ at unbeatable prices ( $\$ 530$ per $\mathrm{kW}$ with wet desulphurisation in 2005), while it does not have experience in building gas turbines, as well as to the very favourable con-

9. David Kelly, "China's power capacity soars", Financial Times, 6 February 2007. The installed capacity in 2006 is far greater than what had been announced. A revision may be necessary in the light of definitive data.

10. Thomas Land, "China puts its faith in nuclear power", Energy Economist, no. 273, July 2004, p. $15-19$.

11. $20 \%$ in 2050 is not unrealistic if large-scale hydroelectric power is included, which the documents in our possession do not specify. Responsibility for the other sources is supposed to be assumed by the China Energy Conservation Investment Corporation (CECIC), which is proposing to invest 2.47 billion dollars over five years in wind power, biomass and biogas, profiting from the obligation made to the electricity companies in this sector to purchase "green electricity" at a price greater than that of the other branches. Cf. Enerpresse, 29 December 2005.

12. Important gas discoveries were made in 2006 in the Tarim basin, in the Bohai Gulf, the Songliao basin and the Ordos basin, but the time it will take to start exploitation does not seem compatible with strong growth in gas-fired thermal power stations before 2020. Catherine Locatelli, Jean-Pierre Angelier, Quel développement pour le gaz en Chine?, LEPII, Grenoble, pre-print, January 2007. 
Table 1. China Electricity generation in a business-as-usual scenario

\begin{tabular}{l|c|c|c|c|c|c}
\hline & 2005 & $\%$ & 2020 & $\%$ & 2050 & $\%$ \\
\hline Total & 470 & 100 & 1200 & 100 & 2700 & 100 \\
\hline - Thermal, coal & 303 & 64 & 767 & 64 & 1306 & 48 \\
\hline - Thermal, oil & 40 & 9 & 37 & 31 & 26 & 1 I \\
\hline - Thermal, gas & 10 & $2 I$ & 78 & 7 & 269 & 10 \\
\hline - Hydro & 105 & 22 & 211 & 18 & 339 & 13 \\
\hline - Nuclear & 9 & 21 & 34 & 31 & 196 & 7 \\
\hline - Renewable & 3 & 11 & 73 & 6 & 21 \\
\hline
\end{tabular}

Sources. For 2005: NDRC, China Energy Development Report. Also: WETO-HE. Note: the oil-fired plant corresponds in large part to private electricity generation by industry using diesel engines. It is not always included in the electricity statistics, which are limited to the production capacity of the public network. The place given to gas-fired plant is no longer in line with the most recent price developments.

ditions for the supply of the power stations with solid fuel. Present underground in almost all of China's regions, of excellent quality in those of the north (Shanxi, Shaanxi, Mongolia and Ningxia in particular), exploitable at average depths of 300-500 metres, most often in rich, shallowly sloped veins, coal is and will remain abundant. With reserves evaluated at $96 \mathrm{Gt}$ (12.2\% of the world's reserves), China is ranked just behind the United States and Russia. Its resources, estimated at $888 \mathrm{Gt}$, or $22 \%$ of global resources, make it the second coal power behind Russia ${ }^{(13)}$. The best deposits can be exploited at costs less than $\$ 20 /$ ton, which ensures a low price for the electricity at the modern power stations built at the pit heads. The length of transportation ( $800 \mathrm{~km}$ on average), and the mediocre quality of some of them, makes the fuel delivered to the southeast coast dearer, but at a price of $\$ 60 /$ ton, it is still without rival for the generation at the thermoelectric power stations. Outside its use as a means of industrial and domestic heating which will not totally disappear, the growth in demand for it in steel-making and in the electricity industry sets its production on a trajectory that will see it double, as a minimum, from here to 2050, perhaps even more if the great adventure of synthetic fuel succeeds.

\section{China, taking the lead in coal-to-liquids (CTL) projects}

Everything had started well for the Chinese oil industry. The prospecting campaigns conducted with the assistance of the Soviet Union at the time of the First Five-Year Plan (1953-1957) resulted in the discovery of several deposits, including those at Daging in 1959 and Shengli in 1962. Rapid (too rapid?) exploitation brought production up to more than 100Mt in 1978, encouraging China to become an exporter and inspiring the dream of becoming a new Saudi Arabia! The 1980s were marked by a return to reality, soon followed by a call for imports and by a growing external dependence. Since that period, the experiences of Germany in the 1930s and South Africa in the embargo years have interested China. The idea of reducing imports of crude petroleum by liquefying coal has gained ground.

Numerous projects have been launched in the course of the last few years. The most ambitious is that of the Shenhua Group in the autonomous region of Mongolia: on the basis of a direct liquefaction process (Bergius type) perfected in China, it has the ambition of producing 5 Mtep by 2010 , then 15Mtep and 30Mtep by 2015 and 2020. Parallel to that, indirect liquefaction (Fischer-Tropsch type) has not been forgotten: in partnership with the big South African company Sasol, the Shenhua Group and its subsidiary

13. While the reserves are of measured quantities and judged to be exploitable at current prices, the resources are not and result only from the geological knowledge of the ground. The above data is taken from the Bundesanstalt für Gewissenschaften und Rohstoffe (BGR), Reserves, Resources and Availability of Energy Resources 2004, 68 p. The BGR estimates of the resources seem more reasonable than those of the US Department of Energy, which has suggested volumes four times as high. The Chinese studies suggest recoverable resources of $1,000 \mathrm{Gt}$ and proven reserves of $114.5 \mathrm{Gt}$, which could be increased to $284.5 \mathrm{Gt}$ by 2020 depending on large-scale investments in exploration. 
(2)

Ningxia Coal Industry is planning the construction of two plants of 3.6Mtep in the province of Shaanxi and in the autonomous region of Ningxia. Thirty or so other projects have been announced, including those of the Lu'an Group in Shanxi (5.2Mtep in 2016), of the Yankuang Group in Shaanxi (10Mtep in 2020) and the one of Shenhua in partnership with Shell. If all of them materialise, China could produce within 15 years more than 70Mtep, absorbing around 210Mtep of coal that for reasons of quality has little recoverable value otherwise on the fuel market ${ }^{(14)}$. Moreover, it would take a certain lead over the industries of other countries also attracted by synthetic fuels, but less convinced of the possibilities and thus not ready to commit heavy investment to them at the moment.

\section{An increasingly high-performance coal in- dustry}

The high coal demand prospects for coal will have more chance of becoming reality as Chinese industry becomes capable of fulfilling them. Without excluding an increased recourse to the importation of certain types of coal required by the industries on the southeast coast, a strong expansion of Chinese coal capacities seems highly likely. After having encouraged the development of the Local State Mines (LSM) and Small Local Mines (SLM), which has enabled it to get around the rigidities and the delays in the expansion of the Central State Mines (CSM) between 1978 and 1996, the Chinese government has instigated a far-reaching restructuring of the whole coal industry centred around a dozen very large companies (from 50 to $100 \mathrm{Mt} /$ year), which have been called on to become vertically integrated and oriented on electricity generation and the production of synthetic fuels. Gradually, these latter are taking over the market shares of other categories of mines, including the very small peasant mines that the authorities are attempting to close with more or less success ${ }^{(15)}$. At the head of this new industry, companies such as Shenhua, Shanxi Coking, Datong Coal, Yankuang, Yanzhou, Huainan, Pingdinghan, Zaozhuang, which are modernising the extraction and the processing of coal, are raising productivity and the safety of the miners' work, installing large-scale thermal power stations at the pit heads and constructing railways to loosen the bottleneck affecting the coal's outlet. Concerned about geographically diversifying their mining patrimony, some have not hesitated to open new mines in Mongolia or take shares in Australian mines ${ }^{(16)}$. According to the latest report by the National Development and Reform Commission (at the end

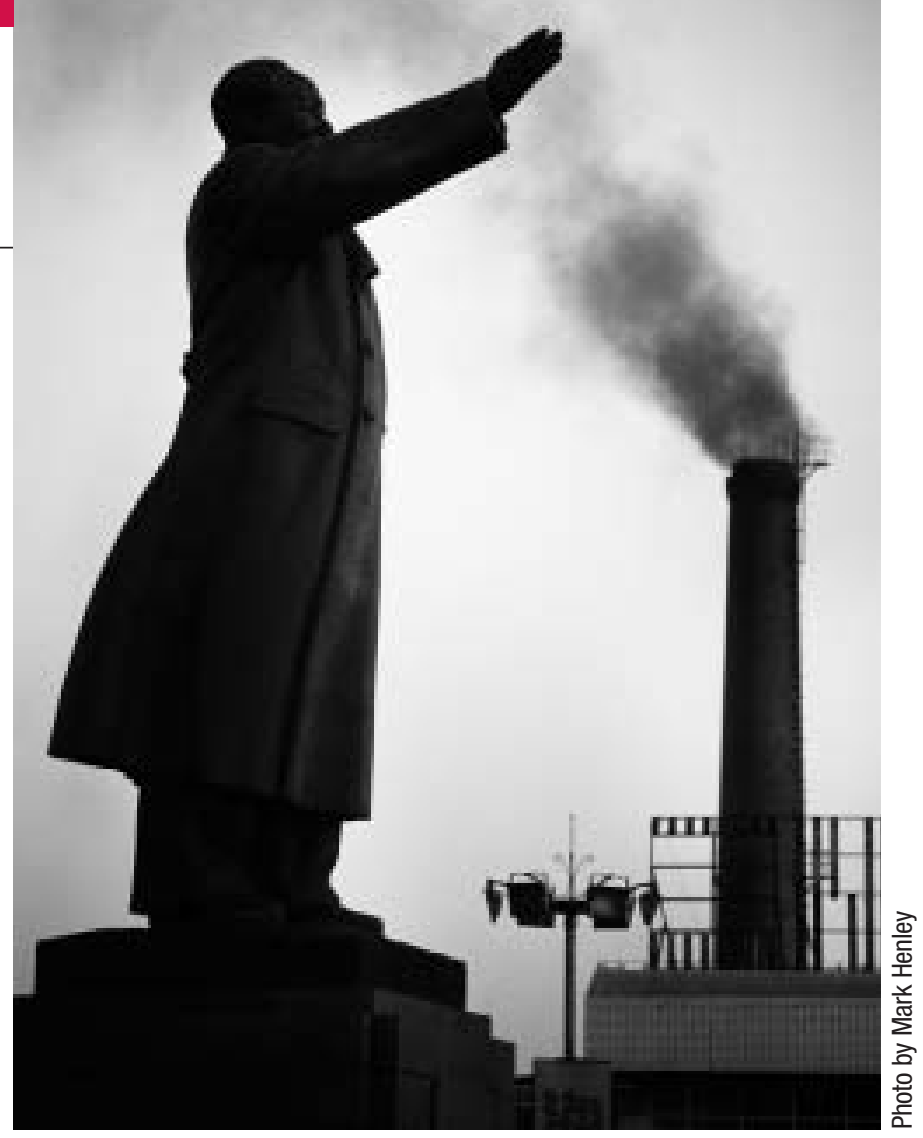

of January 2007), production should become established at $2.6 \mathrm{Gt}$ in 2010 , of which $56 \%$ will be supplied by the very large mines, and perhaps at $3.4 \mathrm{Gt}$ in 2030 .

\section{The government confronted with the challenge of atmospheric pollution}

\section{Environmental impact: taboos that are being knocked down}

The combustion of coal by domestic households, industry and the thermal power stations is not the only source of polluting emissions in a country that continues to burn huge quantities of biomass in installations of little efficiency and that is playing the card of a rapid expansion of road transport (see table 2). But, while in the developed world today these diverse sources of pollution have happened one after the other, in China they are being combined. Their emis-

14. This programme could be reduced according to a NDRC authority (9 June 2007). Among the reasons for this possible reduction, are the high costs of investment, the insufficient evaluation of water resources and the Shenhua Group lack of experience in direct liquefaction. The indirect liquefaction projects, however, would not be changed.

15. The small mines are responsible for $74 \%$ of the 2.73 miners killed per million tons extracted, compared with 0.24 in India and 0.04 in the United States in 2005. Tu Jianjun, "Safety challenges in China's coal mining industry", China Brief, The Jamestown Foundation, vol. $7, \mathrm{n}^{0} 1$.

16. Jean-Marie Martin-Amouroux, "Le charbon-roi, jusqu'à quand?", Revue de l'Energie, $\mathrm{n}^{\circ}$ 563, January-February 2005, pp. 14-18; "Charbon: les métamorphoses d'une industrie", Revue de l'Energie, $\mathrm{n}^{0}$ 573, September-0ctober 2006, pp. 305-313; article "Charbon" in T. Sanjuan (ed.), Dictionnaire, op. cit., pp. 36-37. 
Table 2. Pollutants and $\mathrm{CO}_{2}$ emissions by sector in China (2004)

\begin{tabular}{l|c|c|c}
\hline$\%$ & $\mathrm{SO}_{2}$ & Particulates & $\mathrm{CO}_{2}$ \\
\hline - electricity production & 54.2 & 25.3 & 40.0 \\
\hline - non-metallic ores & 11.2 & 42.1 & 10.1 \\
\hline - other industries & 23.1 & 21.9 & 15.2 \\
\hline - transport, residential & 11.5 & 10.7 & 100.0 \\
\hline Total & 100.0 & 100.0 & \\
\hline
\end{tabular}

Source. Hongliang Yang, op. cit, pp. 13-14. Coal mines are included in non-metallic ores.

sions are known and have been published since 1980 (see table 3). The volumes of sulphur dioxide $\left(\mathrm{SO}_{2}\right)$ seemed to increase by $50 \%$ and those of particulates by $67 \%$ between 1980 and 1995, before falling 20\% and 60\% respectively up to 2002. At this date, the two polluting emissions, of which $80 \%$ to $90 \%$ comes from the burning of coal, resumed their rise, a particularly pronounced rise for $\mathrm{SO}_{2}{ }^{(17)}$. Emissions of nitrogen oxide $(\mathrm{NOx})$ have never ceased growing, but their doubling between 2000 and 2004 can be blamed on road traffic and not electricity production, which now only represents $35 \%$ of the $20 \mathrm{Mt}$ discharged into the atmosphere each year.

At the beginning of the 1990s, particulates ranging from 10 to $100 \mathrm{t} / \mathrm{km}^{2}$ per month fell on the residential districts of the big Chinese cities, several hundreds and sometimes a million $\mathrm{t} / \mathrm{km}^{2}$ on the industrial zones. The norm for suspended particulates of $0.15 \mathrm{~g} / \mathrm{m}^{3}$ was exceeded ten to twentyfold in these same places, particularly in winter when all the buildings were heated using coal. While the concentrations of sulphur dioxide $\left(\mathrm{SO}_{2}\right)$ topped out at a ceiling of between 20 to $100 \mathrm{\mu g} / \mathrm{m}^{3}$ in urban zones in North America, they have frequently reached 500 to 2,000 in the big cities of northern China ${ }^{(18)}$. The situation does not seem to have improved appreciably since then. In $2005,40 \%$ of Chinese territory was affected by acid rain that permeates the soil, the watercourses and the vegetation, especially in the south. Much underground water has become unfit for consumption. The elevated content of $\mathrm{SO}_{2}, \mathrm{NOx}$, particulates and heavy metals in the atmosphere of urban and industrial zones is the root cause of the abnormally high rates of morbidity and mortality ${ }^{(19)}$. What is more, these environmental impacts are spreading outside China, in the direction of Korea, Japan and even the United States if one believes those who de- nounce the wrongdoings perpetrated by the mercury emitted by Chinese coal on the health of the populations of North America ${ }^{(20)}$.

Pushed to act, the central authorities promulgated in 1987 a law governing the control of atmospheric pollution, the rigour of which has been reinforced several times, particularly by the law of 1995 governing the electricity industry. They also set up the State Environmental Protection Administration (SEPA), equivalent to a ministry, in 1998. SEPA, which has set emission standards and put in place monitors charged with the job of ensuring their compliance, is succeeding in getting very polluting installations closed down and in interrupting projects undertaken without a prior environmental impact study. In spite of the limits relating to its administrative partitioning and the weakness of the investments in environmental protection ${ }^{(21)}$, SEPA has worked actively in the energy field. It has made obligatory the installation of desulphurisers in all new thermal power stations (50GW have been fitted out), forced the closure of the most polluting small units $(<50 \mathrm{MW})$ with $30 \mathrm{GW}$ having been closed in 2005, and the rest to be closed by 2010-, urged the electricity industry to equip itself with electrostatic dust

17. The verb "to seem" is used to take into account the change in the statistical base that was made in 1995 (see note to table 3).

18. Vaclav Smil, Energy in China, op. cit., p. 214-224.

19. Lung cancers, 70 to $80 \%$ of which are attributed to atmospheric pollution, have become the leading cause of mortality in Beijing, according to the State Environmental Protection Administration (SEPA).

20. "Invisible Export: A Hidden Cost Of China Growth: Mercury Migration", The Wall Street Journal, 17 December 2004.

21. These have grown from $1 \%$ of GDP in 2001 to $1.3 \%$ in 2005 , but not yet reached the $2 \%$ recommended by the World Bank. "The health of a nation", Business China, 26 February 2007. 
Table 3. Evolution of pollutants and $\mathrm{CO}_{2}$ emissions in China

\begin{tabular}{l|c|c|l|l}
\hline $\mathbf{M}$ tons & $\mathrm{SO}_{2}$ & \multicolumn{1}{c}{$\mathrm{CO}_{2}$} \\
\hline $\mathbf{1 9 8 0}$ & 16.00 & 14.85 & 1,396 \\
\hline $\mathbf{1 9 8 5}$ & 13.24 & 12.95 & 2,728 \\
\hline $\mathbf{1 9 9 0}$ & 14.95 & 13.24 & 2,256 \\
\hline $\mathbf{1 9 9 5}$ & 23.70 & 24.71 & 2,977 \\
\hline $\mathbf{2 0 0 0}$ & 19.95 & 11.65 & 2,935 \\
\hline $\mathbf{2 0 0 1}$ & 19.48 & 10.70 & 2,999 \\
\hline $\mathbf{2 0 0 2}$ & 19.27 & 10.12 & 3,208 \\
\hline $\mathbf{2 0 0 3}$ & 21.59 & 10.49 & 3,719 \\
\hline $\mathbf{2 0 0 4}$ & 22.55 & 10.95 & 3,831 \\
\hline $\mathbf{2 0 0 5}$ & 25.49 & 11.83 & \\
\hline
\end{tabular}

Sources. For SO2 and particulates: China Energy Databook. The bases for the series were modified in 1995. For CO2, IEA, CO2 Emissions from fuel combustion (2006).

collectors (the State Power Corporation installed 318 of them in the course of the Ninth Five-Year Plan) and, more recently, selective catalytic reducers for reducing nitrogen oxide ${ }^{(22)}$. Furthermore, from July 2003, a tax of 0.6 yuan per equivalent standard pollutant has been imposed on emissions of $\mathrm{SO}_{2}$, dust, mercury, carbon monoxide and soot. The influence of the tax on the costs of $\mathrm{kWh}$ is so feeble, however, that it only has little stimulating effect, but the authorities are committed to progressively raising the amount ${ }^{(23)}$. Recently, these measures have not yet borne all their fruit. The authorities are anticipating a reduction in polluting emissions of $10 \%$ in the course of the Eleventh Five-Year Plan, then of $30 \%$ to $60 \%$ of their 2000 levels by 2020 . Their task will not be easy if one trusts the projections for the emission of $\mathrm{SO}_{2}$ and $\mathrm{NO}_{x}$ that were published by the Energy Research Institute in China (ERI) at the end of $2003^{(24)}$.

\section{The prevention of climate change not yet a priority}

Does the desire to reduce polluting emissions extend to emissions of $\mathrm{CO}_{2}, 80 \%$ of which can be attributed to the burning of coal? From 1980 to 2003, these emissions rose from 1.4 to $3.7 \mathrm{Gt}$, that is an annual growth rate of $4.3 \%$, far greater than that of $1.5 \%$ for the whole world ${ }^{(25)}$. But the evolution from 2004 to 2006 is even more worrying, as the interruption to the lowering of the energy intensity is being translated by a rise in China's GDP carbon intensity, something which could advance by a dozen years the date when China tops the table of the largest worldwide emitters of $\mathrm{CO}_{2}$, with 7Gt in 2020 and then $9 \mathrm{Gt}$ in 2030 . This prospect does not seem capable of inflecting the policy of the Chinese government. Since it ratified the Kyoto protocol, it has adhered to the principles of "common but differentiated responsibilities" and of "to each according to its means". In its eyes, the risks of global warming must be combated first of all by the developed countries, who have the historical responsibility for it, then by the other countries who will subordinate their efforts to the requirements of their own development ${ }^{(26)}$. The Eleventh Five-Year Plan

22. At the end of 2006, 15 units were installed in the power stations of Houshi, Songyu, Taicang, Henyun and Ninghai.

23. Asia Pacific Energy Research Center, Energy in China: Transportation, Electric Power and Fuel Markets, 2004, pp. 68-69.

24. They are recapitulated by Noureddine Berrah, La Chine, op. cit., p. 12.

25. International Energy Agency, CO2 Emissions from Fuel Combustion, Paris, OCDE, 2005.

26. Xu Huaqing (project leader), China National Energy Strategy and Policy 2020. Subtitle 7: Global Climate Change: Challenges, Opportunities, and Strategy Faced by China National Development and Reform Commission. Document not referenced, 45 pp. 
U

poor efficiency. It is therefore by renewing its thermal power generation with more modern power stations that China's electricity industry will make the most significant contribution to the reduction of pollution and GGS. And this is something it has been doing since it adopted large size (600MW) supercritical cycles which allow efficiency of $45 \%$ and which are all fitted with equipment to eliminate dust and most of the $\mathrm{SO}_{2}$. In 2005, 132 such units were ordered, and when they come on stream they will contribute to a net improvement in air quality ${ }^{(30)}$, especially if the coal industry supplies them with a higher proportion of washed coal.

\section{In the longer term: coal gasification, com- bined cycle turbines and capture and stor- age of $\mathrm{CO}_{2}$}

The supercritical cycles could constitute only one step towards coal burning that is cleaner and that at the same time emits less $\mathrm{CO}_{2}$. China is therefore working on several paths, most often in partnership with large foreign construction groups such as Mitsubishi, Hitachi, Mitsui Babcock, Alstom or Siemens: ultra-supercritical cycles, recommended by the National Development and Reform Commission (NDRC), which could achieve efficiency of $50 \%$ by $2020^{(31)}$; large circulating fluidised beds the experience that has been accumulated on them is considerable ${ }^{(32)}$; gasification integrated with a combined cycle (Integrated Gasification Combine

Table 4. Pollutants emissions from three types of power stations

\begin{tabular}{|c|c|c|c|}
\hline $\mathrm{lb} / \mathrm{MWh}$ & $\begin{array}{c}\text { Sub } \\
\text { critical }\end{array}$ & $\begin{array}{l}\text { Super } \\
\text { critical }\end{array}$ & IGCC \\
\hline $\mathrm{SO}_{2}$ & 11 & 1.28 & 0.42 \\
\hline NOx & 3 & 0.94 & 0.18 \\
\hline Particulates (PM 10) & 0.3 & 0.12 & 0.02 \\
\hline co & 1.8 & 1.6 & $0.15-0.34$ \\
\hline Ash & 120 & 85 & 0 \\
\hline Slag & 0 & 0 & 127.5 \\
\hline FGD sludge & 150 & 110.5 & 0 \\
\hline
\end{tabular}

Source: CERA, op. cit, p. 6.
Cycles-IGCC) - a demonstration unit is planned at Yantai (Shandong)-while the Thermal Power Research Institute (TPRI) is studying another project of $120 \mathrm{MW}$ and the China Huaneng Group (CHNG) embarked in 2005 on the ambitious implementation of GreenGen, which in 2020 is supposed to produce electricity and hydrogen with no pollutant or $\mathrm{CO}_{2}$ emissions; polygeneration, which consists in producing, on the basis of a synthesis gas (syngas) that results from mixing several fuels, a large range of products: electricity, hydrogen, fuels, chemical products ${ }^{(33)}$ (very advanced in the field of coal gasification, Shell has granted several groups, such as Sinopec, Shenhua and Dahua, the right to exploit its patents $\left.{ }^{(34)}\right)$; the capture and storage of $\mathrm{CO}_{2}$, with several research and development programmes all set to be launched, one of which enjoys the support of the European Union, which is prepared to take on the additional cost of a demonstration operation in a timeframe up to 2015; the extraction of coal-bed methane, which has taken off since the creation in 1996 of China United Coal Bed Methane (CUCBM), the first implementation of which on the Huabei site (Anhui) could produce $500 \mathrm{Mm}^{3} /$ year of methane $(\mathrm{CMM})^{(35)}$; on-site gasification and transportation by gas pipeline.

If one day it manages to progress from supercritical cycles to IGCCs, China would significantly reduce the polluting emissions of its electricity power stations (see table 4). This

30. It would be possible to go even further in this direction through a programme involving the retrofitting of old power stations with supercritical boilers, which, averaging an additional cost of $10 \%$, would reduce polluting and CO2 emissions by $20 \%$. Cf. Eloise Logan, "New coal-burn technology helps China present a cleaner face to the world", Energy Economist, $\mathrm{n}^{0}$ 283, May 2005, pp. 9-12.

31. Mitsui-Babcock, which joined forces with Harbin Boiler $\mathrm{Co}(\mathrm{HBC})$ to push through the take-up of this technology in China, states a figure of $75 \%$. Eloise Logan, "New coalburn technology", loc. cit., p. 11. This information is either incorrect or spin.

32. Six constructors are building installations of more than 100MW: Harbin Boiler Works (49 sold), Dongfang BW (50), Shanghai BW (12), Wuxi BW (12), Jinan BW and Wuhan BW. These last three constructors are working in particular with the IET, which has just brought on stream a 150MW unit in Inner Mongolia, while TPRI has developed a 200MW unit with Harbin Boiler Works and is working on the design of a 300MW unit. In c0-operation with Alstom, twenty or so blocks of 300MW should soon have been constructed. Let us add that China has sold CFBs to Vietnam and to Turkey and that offers have been made in India.

33. Yamashita Kei and Leonardo Barreto, "Energyplexes for the 21st Century: Coa Gasification for Co-producing Hydrogen, Electricity and Liquid Fuels", Energy, $n^{\circ} 30$, 2005, pp. 2453-2473.

34. Martin Clark, "No longer a dirty word", Petroleum Economist, October 2004, pp. 30-31.

35. By 2015 , the production of methane extracted from Chinese coal mines could reach 20 $\mathrm{Gm} 3 /$ year, that is $20 \%$ of production or $12.5 \%$ of the national consumption of natural gas. 
technology furthermore presents numerous other advantages: it demands far less cooling water (350-450 gallons/MWh in place of 600-700), which is significant for China's northern regions; it lends itself well to the capture and storage of $\mathrm{CO}_{2}$, something which is indispensable from the perspective of the fight against climate change.

\section{Changes in trajectory? No doubt, but when?}

Barring unforeseeable events (war, serious economic crisis or "miraculous" discovery of giant hydrocarbon deposits), China has no reason to abandon its prospects of strong growth in electricity production primarily based on the burning of coal, which ensures that it enjoys both the lowest costs and security of supply, something to which its leaders are particularly attached. The more widespread application of dust collectors and gas desulphurisers, the replacement of old boilers with higher output supercritical cycles and the use of an increased percentage of washed coal should enable the growth in polluting emissions to be staunched. On the other hand, any change in the trajectory of $\mathrm{CO}_{2}$ emissions seems to be ruled out for a long time. For that to come any earlier would require China to renounce its goals of low electricity prices and security of supply, while resorting massively to Russian gas and sharply accelerating its nuclear and "renewable" programmes. The cost paid for the few years gained on the calendar for the fight against global warming would certainly seem too expensive. On the other hand, it cannot be ruled out that beyond 2020, having mastered the main technologies that emit less $\mathrm{CO}_{2}$ (nuclear, IGCC and carbon capture and storage), and sufficiently powerful to accept a stronger external dependence (on Russian gas, in particular), China will decide to commit itself to the path of reducing its annual GGS. The raising of living standards at home and the concern to gain international respectability abroad should compel it in that direction.

\section{- Translated by Nick Oates}

